Journal of Engineering Sciences, Assiut University, Vol. 37, No. 1, pp. 1 -16, January 2009.

\title{
EFFECT OF CEMENT CONTENT AND CEMENT TYPE ON THE RESISTANCE OF CONCRETE AGAINST CHEMICAL ATTACK
}

\section{Sayed, A. E. and Mohamed, R. A. S.}

Associate Professors, Civil Engineering Department, Faculty of Engineering, El-Minia University, El-Minia, Egypt.

(Received December 17, 2008 Accepted January 13, 2009)

Mortar and concrete are two important construction materials widely used in both domestic and industrial constructions all over the world. A durable concrete is able to withstand the attacks of destructive processes of chemical, physical or mechanical origin, acting externally or arising internally. Chemical salt attack is caused by ingressing salts into cementitious materials, and the reactions with cement hydrates resulting in either the deterioration of the matrix or loss of corrosion protection of the steel reinforcement. The chemical resistances of the materials against deleterious reactions determine the performance of the materials. Cement type and mix proportions are keys to the resistance of concrete against chemical attack.

In this paper, the resistance of concrete against sulfate and chloride attack was investigated in the laboratory by storing different specimens of concrete cubes in a solution of calcium chloride with concentration 5\%, or solution of magnesium sulphate with concentration $5 \%$ or in solution of magnesium sulphate with concentration $5 \%+$ sodium chloride with concentration 5\% at different ages (7, 28, 59, 90 and 180 days). Compressive strength is determined for specimens submerged in the previous chemical solutions. The chemical resistance of concrete is expressed by the percentage of compressive strength losses for those specimens exposed to the chemical attack compared with those similar ones submerged in fresh water. Both specimens were kept in the condition of laboratory temperature. It is of importance to mention that, only external attack was implemented in this research because it is the more common type and typically occurs where water containing dissolved chloride and sulphate penetrate the concrete.

It can be concluded that, the highest values of compressive strength were obtained from concrete mix cured in water (control mix) meanwhile, the lowest values were resulted from mixes cured in a solution of magnesium sulphate with concentration 5\%+sodium chloride with concentration 5\%.

KEYWORDS: Concrete, chemical attack and compressive strength.

\section{INTRODUCTION}

Reinforced concrete is one of the most important structural materials used in construction. It has excellent structural and durability performance. Nevertheless, there 
is evidence of early deterioration when subjected to marine environments and severe chemical attack. The most common cause of deterioration is corrosion of the reinforcement, with subsequent spalling of the concrete. A careful procedure requires to be followed, in both the design and construction stages, to insure long-term performance of this type of concrete structures. Selection of materials, mix design, proper detailing of reinforcement, appropriate construction techniques and a strict control program are the essential parameters to produce a durable marine concrete structure [1-3].

The Knowledge and understanding of sulfate attack in the field of concrete constructions remains inadequate but, there is no doubt that dense concrete, well compacted, and well cured is essential under different conditions to minimize the effect of sulfate attack on concrete. It has been found that the sulphate resistance of concrete depends of the chemical resistance of cement and the physical resistance of concrete. The chemical resistance is strongly influenced by cement composition or cement type, whereas the physical resistance is controlled by the concrete mix proportions and in particular the water cement ratio. Concrete with lower permeability has better physical resistance and thus would resist the penetration of sulphate ions and thereby improve the resistance of concrete [4-8].

The problem of aggressive attack of sulfate and chloride ions has been of considerable scientific and technological interest because this attack is one of the factors responsible for causing damage to concrete. The corrosive action of chlorides is due to the formation of chloroaluminate hydrates, which causes softening of concrete. Sulfate ions can enter into chemical reactions with certain constituents of concrete, producing sulphoaluminate hydrates and gypsum, which cause the expansion of concrete.

Sulfate attack is a complex process involving a sequence of different chemical reactions. There are mainly two mechanisms related to sulphate attack, ettringite and gypsum formation. In general, it is accepted that expansion and cracking are associated with ettringite formation. Strength loss and mass loss are associated with gypsum formation [5]. Also sulphates dissolved in the water are left behind on or near the surface as the water evaporates. In severe cases of prolonged exposure, this type of chemical assault becomes visually evident as a line or band of sulfate ctystals and surface scaling just above the grade line. The scaling in this area is due to the foramation of sulphate crystals immediately below the surface of concrete, which results in the development of tensile stresses that literally force the surface skin of the concrete away from the bulk material, i.e causes spalling of concrete cover[9-10].

There are two basic transport mechanisms for the penetration of chlorides, diffusion of chloride ions and transport of chloride ion combined with water transport. The diffusion resistance of concrete to chloride ions is important as it governs the rate of penetration of chloride ions. Superior diffusion resistance would imply that it will take longer for chloride ion concentration at reinforcement to exceed a critical chloride concentration, for which depassivation and corrosion of steel can take place [8].

Thus, this study utilizes both compression testing and denesity of concrete specimens to examine the effect of sulfate and chloride attack on concrete and to better indicate the effect of cement type and cement content on the concrete's ability to resist such attack. 


\section{EXPERIMENTAL WORK}

The experiments include the measurements of the compressive strength of concrete cubes $15 \times 15 \times 15 \mathrm{~cm},(240$ cubes in total $)$ cured and tested at different ages. Two main groups of cubes were made of cement contents equal to 250 and $350 \mathrm{Kg} / \mathrm{m} 3$. In order to represent the common cement contents normally used with plain and reinforced concrete constructions. Each group were fabricated by using either O.P.C. or C-Water cement and then all groups were exposed to sever chemical attack by submerging them in chloride or sulfate solutions or both for ages 7, 28, 59, 90 and 180 days. The same type of sand and gravel were used, along with water-cement ratio of 0.50 . All test specimens were cured in four different conditions. Details of all concrete test specimens are given in table (1).

Table 1. Details of concrete mixes

\begin{tabular}{|l|l|l|l|l|l|}
\hline $\begin{array}{l}\text { Group } \\
\text { No. }\end{array}$ & $\begin{array}{l}\text { Cement } \\
\text { Content } \\
\mathrm{Kg} / \mathrm{m}^{3}\end{array}$ & $\begin{array}{l}\text { Sand } \\
\mathrm{Kg} / \mathrm{m}^{3}\end{array}$ & $\begin{array}{l}\text { Gravel } \\
\mathrm{Kg} / \mathrm{m} 3\end{array}$ & $\begin{array}{l}\text { W|C } \\
\text { ratio }\end{array}$ & $\begin{array}{l}\text { Cement } \\
\text { Type }\end{array}$ \\
\hline 1 & 250 & 690 & 1380 & 0.50 & O.P.C \\
\hline 2 & 350 & 600 & 1200 & 0.50 & O.P.C \\
\hline 3 & 250 & 690 & 1380 & 0.50 & C-Water cement \\
\hline 4 & 350 & 600 & 1200 & 0.50 & C-Water cement \\
\hline
\end{tabular}

A natural siliceous sand and gravel from El-Minia quarries were used as a fine and coarse aggregates. The physical and mechanical properties of sand and gravel are given in table (2).

Table 2. Physical properties of sand and gravel

\begin{tabular}{|c|c|c|}
\hline Property & Test results for sand & Test results for gravel \\
\hline Specific weight & 2.65 & 2.65 \\
\hline Volume weight $\left(\mathrm{t} / \mathrm{m}^{3}\right)$ & 1.65 & 1.66 \\
\hline Absorption $(24 \mathrm{hrs})$ & $0.65 \%$ by weight & $1.0 \%$ by weight \\
\hline$\%$ of fine materials & $1.4 \%$ by weight & $0.9 \%$ by weight \\
\hline Crushing value & - & $16 \%$ \\
\hline Voids ratio & $37.7 \%$ & $37.3 \%$ \\
\hline
\end{tabular}

The two types of cement used in this investigation are ordinary portland cement and c-water cement. The mechanical properties of the two types of used cement are given in Table (3). Tap water was used in all concrete mixes. Mixing of concrete components was completed by using a horizontal rotating counter flow mixer pan of 0.09 cubic meter capacity with speed of 13 revolutions per minute. Prior rotating the mixer pan, the pan mixer was wetted and only the half of the amount of sand, gravel were added together into the mixer and mixed for 1 minute. While rotating the cement was added into the mixer. The mixing was performed for another 3 minutes by adding water for the purpose of uniformity. The mixing operation was carried out in accordance to ASTM C (192-81). Before casting directly, the internal surfaces of the moulds were coated with a thin layer of mineral oil to avoid the development of bond 
between the mould and the concrete. Fresh concrete was taken from the mixer and poured into the moulds in three layers by using blunted trowel. The trowel was moved around the top edge of the cube in order to insure a symmetrical distribution of the concrete and to minimize segregation of coarse aggregate. Each layer of concrete was compacted using a standard compacting rod, after compacting the third layer was compacted by a mechanical vibrator.

Table 3-a. Properties of the used ordinary Portland cement (O. P. C )

\begin{tabular}{|c|c|c|}
\hline Mechanical properties & Test results & E.S.S limits \\
\hline Specific gravity & 3.15 & 3.15 \\
\hline Fineness \% & $6.2 \%$ & Max $10 \%$ \\
\hline Specific surface $\mathrm{cm}^{2}$ /gr. & 3975 & Min 2500 \\
\hline Water demand \% & 26 & Min 25, max 30 \\
\hline Initial setting time (minute) & 140 & Min $45 \mathrm{~min}$. \\
\hline Final setting time (minute) & 400 & Max $10 \mathrm{hr}$. \\
\hline Soundness (mm) & $1.0 \mathrm{~mm}$ & Max $10 \mathrm{~mm}$ \\
\hline Compressive strength & & \\
At 3 days Kg/cm & \\
At 7 days $\mathrm{Kg} / \mathrm{cm}^{2}$ & 280 & Min $180 \mathrm{Kg} / \mathrm{cm}^{2}$ \\
& 300 & Min $270 \mathrm{Kg} / \mathrm{cm}^{2}$ \\
\hline
\end{tabular}

Table (3-b) Properties of the used C-water cement.

\begin{tabular}{|c|c|c|}
\hline Mechanical properties & Test results & E.S.S limits \\
\hline Specific gravity & 3.15 & 3.15 \\
\hline Fineness \% & $6.1 \%$ & Max $10 \%$ \\
\hline Specific surface $\mathrm{cm}^{2} /$ gr. & 4239 & Min 2800 \\
\hline Water demand \% & 26 & Min $25, \max 30$ \\
\hline Initial setting time (minute) & 100 & Min $45 \mathrm{~min}$. \\
\hline Final setting time (minute) & 170 & Max $10 \mathrm{hr}$. \\
\hline Soundness (mm) & $1.0 \mathrm{~mm}$ & Max $10 \mathrm{~mm}$ \\
\hline Compressive strength & & \\
At 3 days Kg/cm & 329 & Min $180 \mathrm{Kg} / \mathrm{cm}^{2}$ \\
At 7 days Kg/cm & 390 & Min $270 \mathrm{Kg} / \mathrm{cm}^{2}$ \\
\hline
\end{tabular}

After that, the top surfaces of the cubes were finished and leveled with a metal trowel, and then the specimens were kept in the laboratory and covered by plastic sheets for 24 hours to prevent rapid moisture evaporation and plastic shrinkage. All the concrete specimens were cast and compacted according to the Egyptian Standard Specifications (ESS). Cubes were demoulded after 24 hours, and then, cured in four different conditions until the testing time as follows; the first group is submerged in a container full of tap water, the second one is submerged in a solution of $5 \%$ calcium chloride concentration, the third one is submerged in a solution of 5\% magnesium sulfate concentration and the last one is submerged in other full of a solution contains $5 \%$ calcium chloride $+5 \%$ magnesium sulfate. All specimens were dried for 24 hours before testing. The compressive strength test was carried out on the specimens at the ages of 7, 28, 59, 90 and 180 days. 


\section{TEST RESULTS AND DISCUSSION}

The compressive strength results obtained from testing the concrete cubes of group (1) which made of O.P.C content $=250 \mathrm{Kg} / \mathrm{m} 3$ and cured in the four mentioned curing regimes $\left(\mathrm{H}_{2} \mathrm{O}, 5 \% \mathrm{CaCl}_{2}, 5 \% \mathrm{MgSO}_{4}\right.$ and $\left.5 \% \mathrm{NaCl}+5 \% \mathrm{MgSO}_{4}\right)$ for the different periods of time are recorded in table (4) and plotted in fig. (1).

Table 4. Compressive strength values of concrete made of O.P.C with cement content $=250$ of $\mathrm{Kg} / \mathrm{m}^{3}$.

\begin{tabular}{|c|c|c|c|c|}
\hline \multicolumn{5}{|c|}{ Average compressive strength $\left(\mathrm{Kg} / \mathrm{cm}^{2}\right)$. } \\
\hline $\begin{array}{ll} & \text { Curing conditions } \\
\text { Time (days) }\end{array}$ & $\mathrm{H}_{2} \mathrm{O}$ & $\mathrm{CaCl}_{2}$ & $\mathrm{MgSO}_{4}$ & $\mathrm{NaCl}+\mathrm{MgSO}_{4}$ \\
\hline 7 & 200 & 205 & 176 & 155 \\
\hline 28 & 270 & 238 & 200 & 186 \\
\hline 59 & 275 & 243 & 223 & 210 \\
\hline 90 & 278 & 250 & 235 & 230 \\
\hline 180 & 285 & 255 & 208 & 210 \\
\hline
\end{tabular}

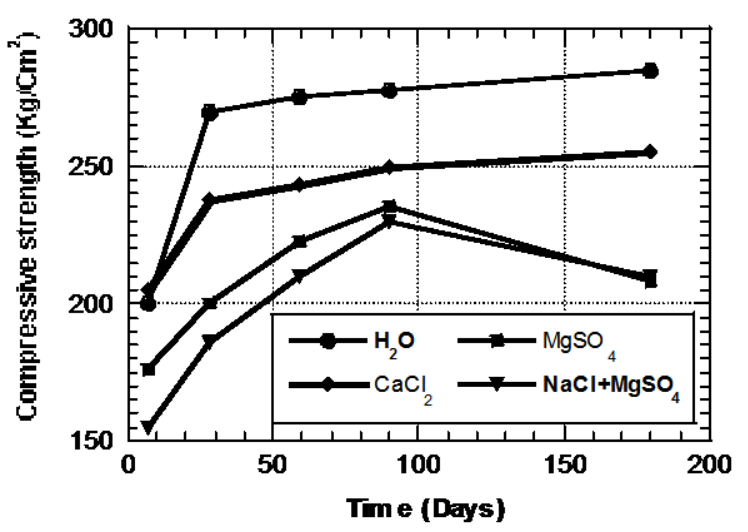

Fig. 1 Relationship between compressive strength and period of curing for cubes made of O.P.C with cement content $=250 \mathrm{Kg} / \mathrm{m}^{3}$.

Table (4) and figure (1) indicated generally that, the compressive strength of concrete cubes increased with increasing time regardless of curing solution up to 90 days beyond that, the compressive strength at 180 days was decreased with specimens cured in the solution of $5 \% \mathrm{MgSO} 4$ and the mixture of $5 \% \mathrm{NaCl}+5 \% \mathrm{MgSO} 4$. This reduction can be attributed to the sulfate attack which comes from the curing solutions. In general, the highest values of compressive strength were obtained from concrete mix cured in water (control mixes) except for the first few days, the mix cured in calcium chloride solution produced slightly higher strength than other mixes (up to 7 days) 
meanwhile, the lowest values were resulted with mixes cured in the solution of sodium chloride and magnesium sulfate at all ages of curing.

The percentage decrease in compressive strength of this group was calculated with respect to time and recorded in table (5) as well as illustrated in figure (2). The percentage decrease in strength due to curing specimens in calcium chloride was found to be about $10 \%$ regardless of the ages of curing conditions. This decrease in strength attributed to the effect of the two transport mechanisms for the penetration of chlorides, diffusion of chlorides and transport of chloride ion combined with water. The diffusion resistance of concrete to chlorides is important as it governs the rate of penetration of chloride ions [8].

Submerging concrete cubes in sulphatic solutions causes a higher reduction in strength ranging from $15-30 \%$. This strength reduction occurred as a result of the deterioration of concrete due to the penetration of magnesium sulfate into the concrete samples [8] because sulfate attack is a complex process involving two mechanisms: ettringite and gypsum formation. Expansion and cracking are associated with ettringite formation. Strength loss is associated with gypsum formation $[5,11]$.

Table 5. The percentage increase in strength against time for mixes cured at different curing conditions.

\begin{tabular}{|c|c|c|c|c|c|c|}
\hline \multirow{2}{*}{ Time (days) } & \multicolumn{5}{|c|}{ \% Increase in strength } & \multirow{2}{*}{ Remarks } \\
\cline { 2 - 6 } & 7 & 28 & 59 & 90 & 180 & \\
\hline $\mathrm{CaCl}_{2}$ & +2.50 & -11.9 & -11.6 & -10.1 & -10.5 & $\mathrm{C}=250$ \\
\cline { 1 - 6 } $\mathrm{MgSO}_{4}$ & -12.0 & -25.9 & -18.9 & -15.5 & -27.0 & $\mathrm{Kg} / \mathrm{m}^{3}$ \\
\cline { 1 - 6 } & $(\mathrm{O} . \mathrm{P} . \mathrm{C})$ \\
\hline $\mathrm{NaCl}+\mathrm{MgSO}_{4}$ & -22.5 & -31.1 & -23.6 & -17.3 & -26.3 & \\
\hline
\end{tabular}

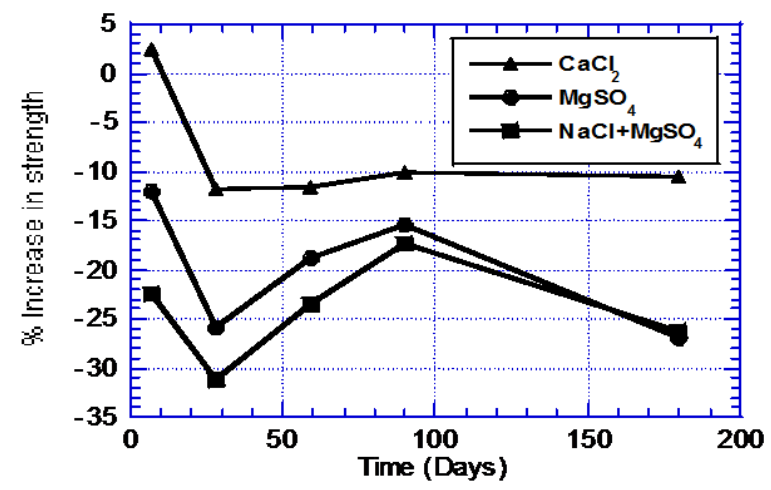

Fig. (2) Relationship between \% increase in strength and period of curin for cubes made of O.P.C with cement content $=350 \mathrm{Kg} / \mathrm{m}^{3}$.

Similar concrete mix was used to fabricate the cubes of group (2) expect of using cement content equals to $350 \mathrm{Kg} / \mathrm{m}^{3}$ instead of $250 \mathrm{Kg} / \mathrm{m}^{3}$. Table (6) as well as figure (3) give the relationship between $\mathrm{Fc}\left(\mathrm{Kg} / \mathrm{cm}^{2}\right)$ and time (days) for cubes cured in the same four solutions for periods of 7, 28, 59, 90 and 180 days. Similar trends for the compressive strength against time were observed 
Table 6. Compressive strength values of concrete made of O.P.C with cement content $=350$ of $\mathrm{Kg} / \mathrm{m}^{3}$.

\begin{tabular}{|cc|c|c|c|c|}
\hline \multicolumn{5}{|c|}{ Average compressive strength $\left(\mathrm{Kg} / \mathrm{cm}^{2}\right)}$. \\
\hline Time (days) & Curing conditions & $\mathrm{H}_{2} \mathrm{O}$ & $\mathrm{CaCl}_{2}$ & $\mathrm{MgSO}_{4}$ & $\mathrm{NaCl}+\mathrm{MgSO}_{4}$ \\
\hline 7 & 240 & 243 & 226 & 200 \\
\hline 28 & 330 & 310 & 293 & 283 \\
\hline 59 & 335 & 320 & 305 & 300 \\
\hline 90 & 343 & 325 & 321 & 315 \\
\hline 180 & 350 & 333 & 305 & 302 \\
\hline
\end{tabular}

The $\%$ decrease in strength of concrete cubes of group (2) due to curing them in the same chemical solutions are given in table (7) and shown in figure (4). The losses in strength due to curing specimens in calcium chloride was found to be about $5 \%$ meanwhile, it was about $15 \%$ with specimens cured in magnesium sulfate solution. However, the condition of curing them in sodium chloride + magnesium sulfate the recorded percentage decrease in strength was about $10 \%$ to $15 \%$. Therefore, it can be concluded that, increasing cement content from, 250 to $350 \mathrm{Kg} / \mathrm{m}^{3}$ improve the compressive strength by about $50 \%$ regardless of the curing regimes which logically leads to enhance the mechanical properties of concrete performance as well as the resistance to chemical attack..

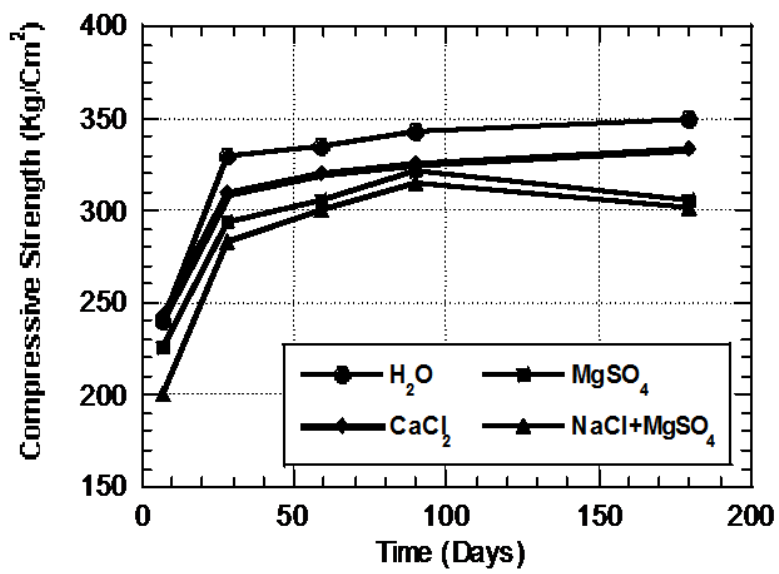

Fig. 3 Relationship between compressive strength and period of curing for tested cubes made of O.P.C with cement content $350 \mathrm{Kg} / \mathrm{m}^{3}$.

Table 7. The percentage increase in strength against time for mixes cured at different conditions.

\begin{tabular}{|c|c|c|c|c|c|c|}
\hline \multirow{2}{*}{ Time (days) } & \multicolumn{5}{|c|}{ \% Increase in strength } & \multirow{2}{*}{ Remarks } \\
\cline { 2 - 6 } Curing conditions & 7 & 28 & 59 & 90 & 180 & \\
\hline $\mathrm{CaCl}_{2}$ & +1.30 & -6.10 & -4.50 & -5.20 & -4.90 & $\mathrm{C}=350$ \\
$\mathrm{MgSO}_{4}$ & -5.80 & -11.2 & -9.00 & -6.40 & -12.90 & $\mathrm{Kg} / \mathrm{m}^{3}$ \\
\hline $\mathrm{NaCl}+\mathrm{MgSO}_{4}$ & -16.7 & -14.2 & -10.4 & -8.20 & -13.70 & (O.P.C) \\
\hline
\end{tabular}




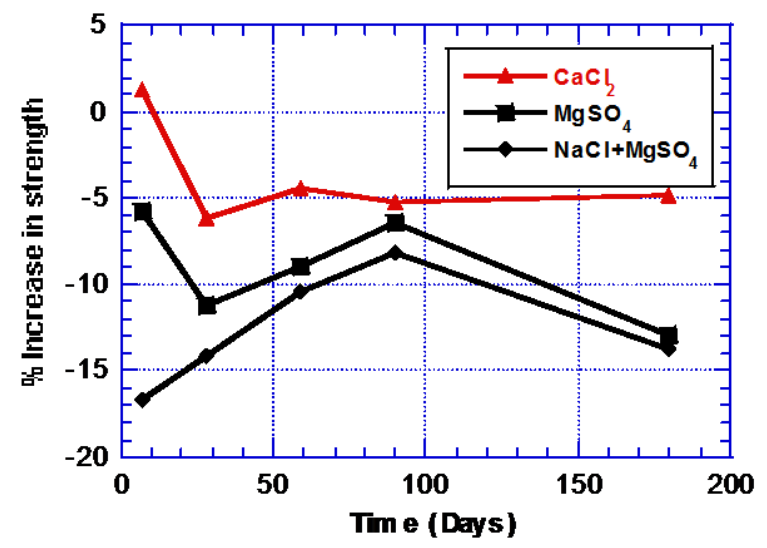

Fig. 4 Relationship between \% increase in strength and period of curing for tested cubes made of O.P.C. with cement content $=350 \mathrm{Kg} / \mathrm{m}^{3}$.

The effect of using C-water cement in concrete mixes instead of ordinary portland cement to enhance the resistance against chemical attack comes from submerging samples in the curing solutions is identified in the following section;

The compressive strength results obtained from the plain concrete mixes made of C-water cement equals to $250 \mathrm{Kg} / \mathrm{m}^{3}$ and cured in the same three different chemical solutions along with water curing are indicated in table (8) and plotted in figure (5).

In general, the highest values of compressive strength were obtained from control concrete mixes ( cured in water ) meanwhile, the lowest strengths were resulted from those mixes cured in the mixture of $\mathrm{NaCl}+\mathrm{MgSO}_{4}$.

Table 8. Compressive strength values of concrete made of $\mathrm{C}$-water with cement content $=250 \mathrm{Kg} / \mathrm{m}^{3}$.

\begin{tabular}{|cc|c|c|c|c|}
\hline \multicolumn{5}{|c|}{ Average compressive strength $\left(\mathrm{Kg} / \mathrm{cm}^{2}\right)}$. \\
\hline Time (days) & Curing conditions & $\mathrm{H}_{2} \mathrm{O}$ & $\mathrm{CaCl}_{2}$ & $\mathrm{MgSO}_{4}$ & $\mathrm{NaCl}+\mathrm{MgSO}_{4}$ \\
\hline 7 & 190 & 196 & 182 & 178 \\
\hline 28 & 255 & 241 & 220 & 215 \\
\hline 59 & 265 & 245 & 230 & 221 \\
\hline 90 & 268 & 250 & 235 & 231 \\
\hline 180 & 270 & 246 & 215 & 220 \\
\hline
\end{tabular}

Test results emphasized the fact that increasing the compressive strength with time particularly, with those mixes cured in water. Other concrete mixes cured in the chemical solutions were resulted a noticeable decrease in strength after 90 days and up to 180 days. The $\%$ decrease in strength of those concrete mixes are given in table (9) and shown in figure (6). 


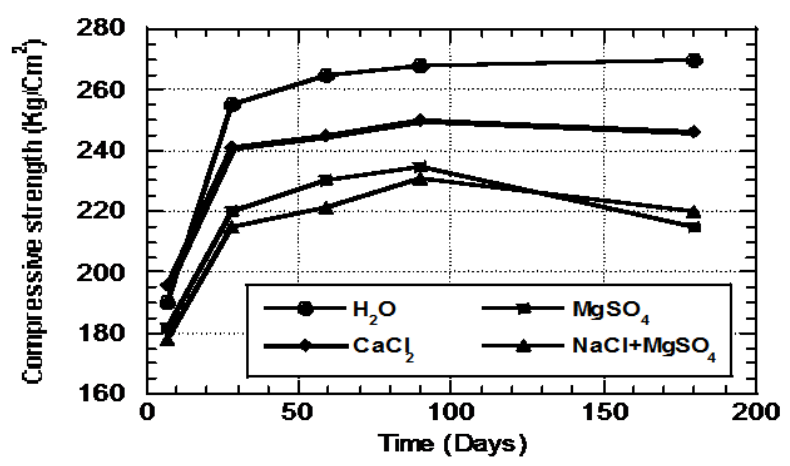

Fig. 5 Relationship between compressive strength and period of curing for cubes made of $C$-water cement with $\mathrm{C}=250 \mathrm{Kg} / \mathrm{m}^{3}$.

It can be concluded that, the rate of decresing the compressive strength of concrete cubes of group (3) cured in the different chimical solutions is found to be highly increased at 180 days. The percentage decrease in strength of those mixes cured in sulphatic solutions is about $20 \%$.

Table 9. The percentage increase in strength against time for mixes cured at different conditions.

\begin{tabular}{|c|c|c|c|c|c|c|}
\hline \multirow{2}{*}{$\begin{array}{l}\text { Time (days) } \\
\text { Curing conditions }\end{array}$} & \multicolumn{5}{|c|}{$\%$ Increase in strength } & \multirow{2}{*}{ Remarks } \\
\hline & 7 & 28 & 59 & 90 & 180 & \\
\hline $\mathrm{CaCl}_{2}$ & +3.15 & -5.50 & -7.50 & -6.70 & -8.80 & \multirow{3}{*}{$\begin{array}{c}\mathrm{C}=250 \\
\mathrm{Kg} / \mathrm{m}^{3} \\
(\mathrm{C}-\text { water })\end{array}$} \\
\hline $\mathrm{MgSO}_{4}$ & -4.20 & -13.7 & -13.2 & -12.3 & -20.4 & \\
\hline $\mathrm{NaCl}+\mathrm{MgSO}_{4}$ & -6.30 & -15.7 & -16.6 & -13.8 & -18.5 & \\
\hline
\end{tabular}

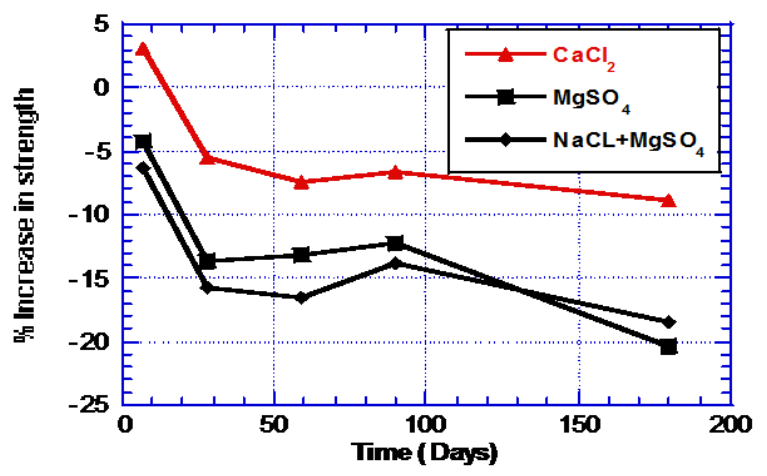

Fig. 6 Relationship between \% increase in strength and period of curing for tested cubes made of C-water with cement content $250 \mathrm{Kg} / \mathrm{m}^{3}$.

Table (10) and figure (7) comprises the test results obtained from concrete mixes of group (4) which they have been fabricated by using $\mathrm{C}$-water cement with 
cement content $=350 \mathrm{Kg} / \mathrm{cm}^{3}$ and cured in the same chemical solutions. Table (11) as well as figure (8) also show the percentage decrease in compressive strength for those mixes.

Table 10. Compressive strength values of concrete made of $\mathrm{C}$-water cement with cement content $=350 \mathrm{Kg} / \mathrm{m}^{3}$.

\begin{tabular}{|cc|c|c|c|c|}
\hline \multicolumn{5}{|c|}{ Average compressive strength $\left(\mathrm{Kg} / \mathrm{cm}^{2}\right)}$. \\
\hline Time (days) & Curing conditions & $\mathrm{H} 2 \mathrm{O}$ & $\mathrm{CaCl}_{2}$ & $\mathrm{MgSO}_{4}$ & $\mathrm{NaCl}+\mathrm{MgSO}_{4}$ \\
\hline 7 & 240 & 246 & 220 & 196 \\
\hline 28 & 325 & 305 & 300 & 295 \\
\hline 59 & 336 & 320 & 315 & 310 \\
\hline 90 & 350 & 330 & 310 & 317 \\
\hline 180 & 354 & 326 & 282 & 295 \\
\hline
\end{tabular}

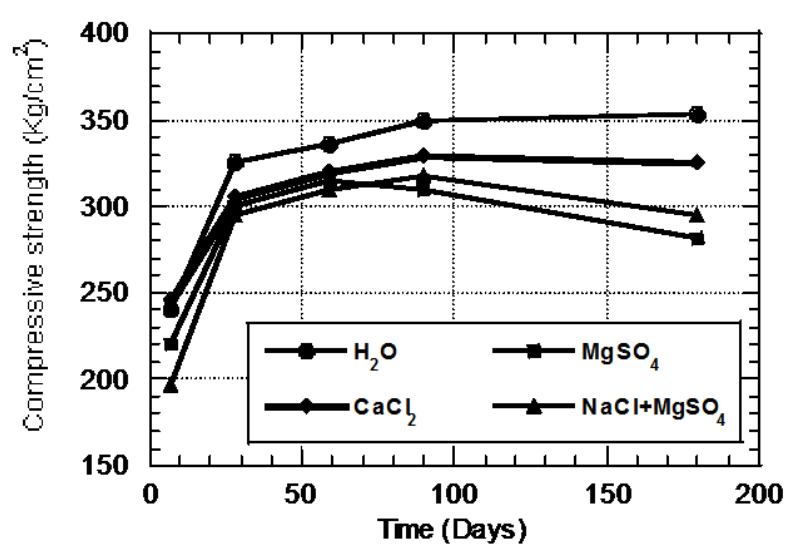

Fig. 7 Relationship between compressive strength and period of curing for cubes made of $C$-water cement with $C=350$ of $\mathrm{Kg} / \mathrm{m}^{3}$.

Table 11. The percentage increase in strength against time for mixes cured at different conditions.

\begin{tabular}{|c|c|c|c|c|c|c|}
\hline \multirow{2}{*}{ Time (days) } & \multicolumn{5}{|c|}{ \% Increase in strength } & \multirow{2}{*}{ Remarks } \\
\cline { 2 - 6 } Curing conditions & 7 & 28 & 59 & 90 & 180 & \\
\hline $\mathrm{CaCl}_{2}$ & +2.50 & -6.20 & -4.80 & -6.10 & -7.90 & $\mathrm{C}=350$ \\
$\mathrm{MgSO}_{4}$ & -8.30 & -8.30 & -6.30 & -11.40 & -20.0 & $\mathrm{Kg} / \mathrm{m}^{3}$ \\
\cline { 1 - 6 } & -18.3 & -9.20 & -7.70 & -9.40 & -16.7 & $(\mathrm{C}-$ water $)$ \\
\hline
\end{tabular}

Similar trends and results have been observed with those concrete mixes made of C-water cement content $=350 \mathrm{Kg} / \mathrm{m}^{3}$ when compared with those mixes made of 250 $\mathrm{Kg} / \mathrm{m}^{3}$. It is of importance to mention that, the percentage decrease in strength has not been influenced by the $\mathrm{C}$-water cement content. 


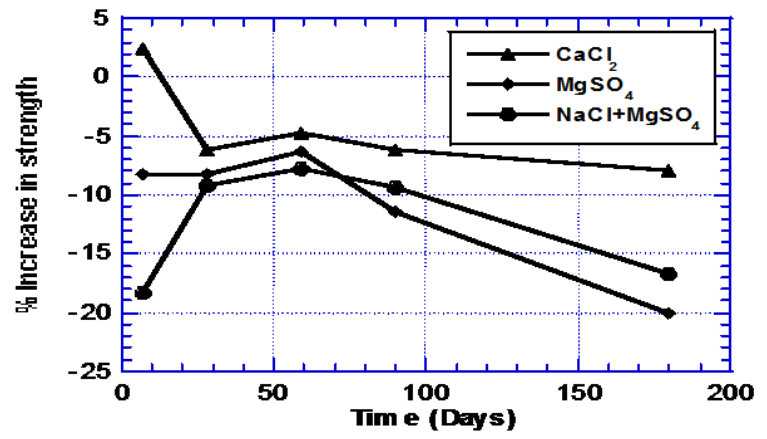

Fig 8. Relationship between \% increase in strength and period of curing for tested cubes made of $C$-water with $C=350 \mathrm{Kg} / \mathrm{m}^{3}$.

To identify the effect of using C-water cement instead of O.P.C in concrete mixes exposed to different curing conditions, the relationships between the compressive strength of concrete cubes $\left(\mathrm{Fc}_{28}\right)$ mad of the two used types of cement with cement contents equal to 250 and $350 \mathrm{Kg} / \mathrm{m}^{3}$ and cured in the different chemical solutions are plotted in figures (9 and 10) respectively.

It can be generally reported that, using $\mathrm{C}$-water cement in concrete mixes enhanced the resistance of concrete against the chemical attack when compared with identical mixes made of O.P.C. Hhowever, figure (10) emphasized that using a relatively high amount of O.P.C content $(350 \mathrm{Kg} / \mathrm{m} 3)$ improved the compressive strength of the concrete mixes when exposed to the sever chemical attack e.g., improved the resistance of concrete against sulphate attack.

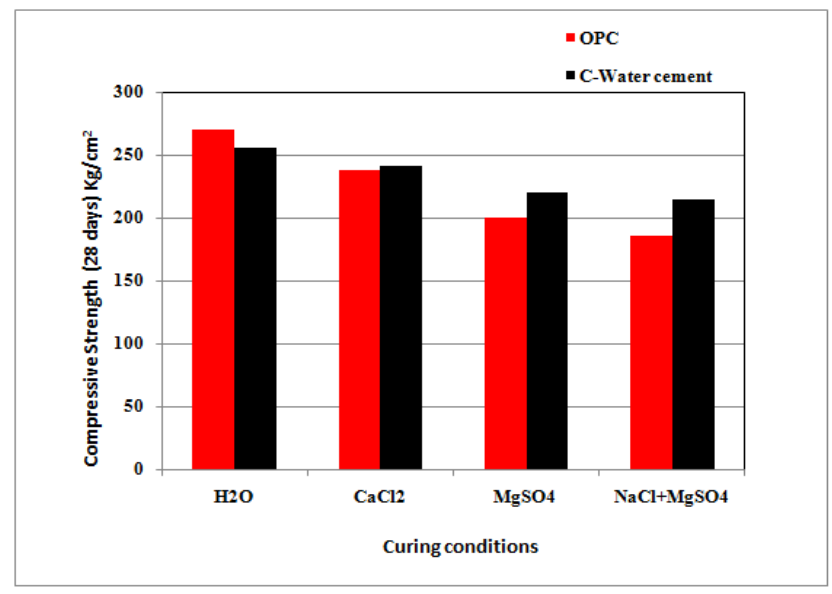

Fig. 9 Relationship between the compressive strength of concrete $\left(\mathrm{Fc}_{28}\right)$ and curing conditons for concrete mixs made of $\mathrm{C}=250 \mathrm{Kg} / \mathrm{m}^{3}$. 


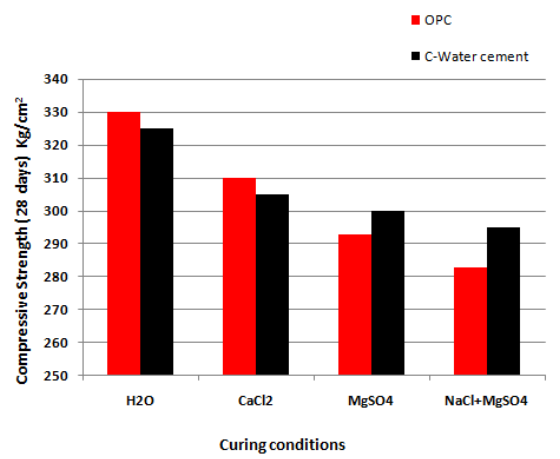

Fig. 10 Relationship between the compressive strength of concrete $\left(\mathrm{Fc}_{28}\right)$ and curing conditons for concrete mixs made of $C=350 \mathrm{Kg} / \mathrm{m}^{3}$.

The effect of submerging concrete mixes in the chemical solutions for a relatively long time (180 days) is illustrated in figures (11 and 12).

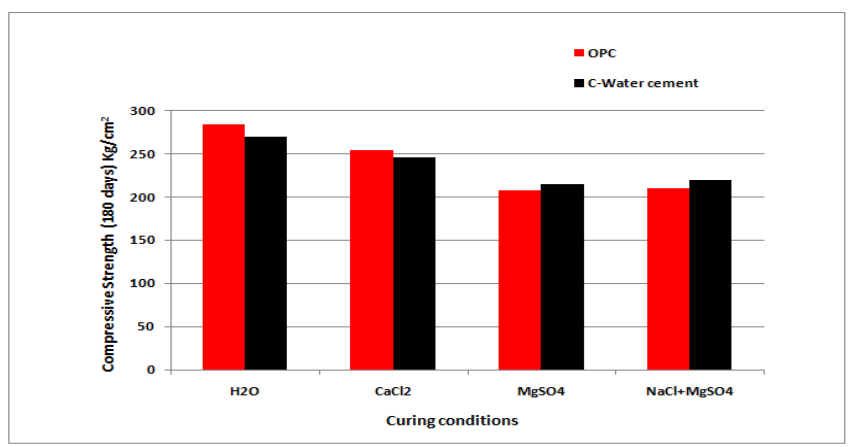

Fig. 11 Relationship between the compressive strength of concrete ( $\mathrm{Fc} 180)$ and curing conditons for concrete mixs made of $\mathrm{C}=350 \mathrm{Kg} / \mathrm{m}^{3}$.

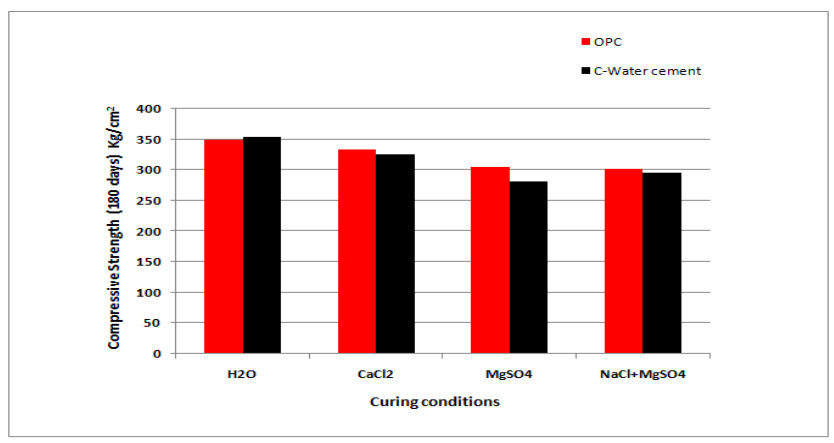

Fig. 12 Relationship between the compressive strength of concrete (Fc180) and curing conditons for concrete mixs made of $\mathrm{C}=350 \mathrm{Kg} / \mathrm{m}^{3}$.

It can be generally concluded that, increasing O.P.C content from 250 to 350 $\mathrm{Kg} / \mathrm{m}^{3}$ in concrete mixes resulted a significant increase in the compressive strength when compared with $\mathrm{C}$-water cement mixes. 
The average values of density, obtained from weighing the concrete cubes after 28 and 180 days, are shown in tables (12 and 13) respectively. These values were determined after taking them off the curing solutions and leaving them to be dried.

The average values of density are about $2.2 \mathrm{t} / \mathrm{m}^{3}$ regardless of curing conditions or the type of cement. Only a slight decrease of about $2 \%$ in density was noticed with cubes made of O.P.C and cured in $(5 \%$ Sodium chloride $+5 \%$ Magnesium sulfate) solutions. This slight decrease in density attributed to the effect of sulfate attack for the short period of curing time.

Table 12. The average density values of different concrete mixes cured in different curing conditions (at age of 28 days).

\begin{tabular}{|c|c|c|c|c|}
\hline \multirow{3}{*}{$\begin{array}{l}\text { Curing } \\
\text { conditions }\end{array}$} & \multicolumn{4}{|c|}{ Average density $\mathrm{t} / \mathrm{m}^{3}$} \\
\hline & \multicolumn{2}{|c|}{ Cement content $=250 \mathrm{Kg} / \mathrm{m}^{3}$} & \multicolumn{2}{|c|}{ Cement content $=350 \mathrm{Kg} / \mathrm{m}^{3}$} \\
\hline & O.P.C & C-Water & O.P.C & C-Water \\
\hline $\mathrm{H}_{2} \mathrm{O}$ & 2.175 & 2.19 & 2.23 & 2.21 \\
\hline $\mathrm{CaCl}_{2}$ & 2.183 & 2.2 & 2.23 & 2.227 \\
\hline $\mathrm{MgSO}_{4}$ & 2.183 & 2.2 & 2.218 & 2.244 \\
\hline $\mathrm{NaCl}+\mathrm{MgSO}_{4}$ & 2.19 & 2.183 & 2.21 & 2.21 \\
\hline
\end{tabular}

Table 13. The average density values of different concrete mixes cured in different curing conditions (at age of 180 days).

\begin{tabular}{|c|c|c|c|c|}
\hline \multirow{3}{*}{$\begin{array}{l}\text { Curing } \\
\text { conditions }\end{array}$} & \multicolumn{4}{|c|}{ Average density $\mathrm{t} / \mathrm{m}^{3}$} \\
\hline & \multicolumn{2}{|c|}{ Cement content $=250 \mathrm{Kg} / \mathrm{m}^{3}$} & \multicolumn{2}{|c|}{ Cement content $=350 \mathrm{Kg} / \mathrm{m}^{3}$} \\
\hline & O.P.C & C-Water & O.P.C & C-Water \\
\hline $\mathrm{H}_{2} \mathrm{O}$ & 2.21 & 2.194 & 2.24 & 2.22 \\
\hline $\mathrm{CaCl}_{2}$ & 2.183 & 2.2 & 2.234 & 2.227 \\
\hline $\mathrm{MgSO}_{4}$ & 2.192 & 2.192 & 2.22 & 2.218 \\
\hline $\mathrm{NaCl}+\mathrm{MgSO}_{4}$ & 2.175 & 2.187 & 2.20 & 2.21 \\
\hline
\end{tabular}

It has been reported in the literature that [12], concrete quality is the most important issue in sulfate attack. The negative effects of environment, sulfate concentration, and composition are most noticeable in concrete of lower quality. Highquality concrete-- concrete that has been properly designed and cured to reach high density will not suffer from sulfate attack which agrees with the previous density results in this research.

\section{CONCLUSIONS}

Based on the present study, the following conclusions, with respect to the effect of cement type and content on the resistance of concrete against chemical attack, are drawn ;

1. The highest values of compressive strength were obtained from concrete mixes cured in water (control mixes) meanwhile, the lowest values were recorded for mixes cured in the sulphatic solutions. The sever condition of chemical attack 
occurred when the O.P.C concrete specimens cured in the solution of sodium chloride and magnesium sulphate. The percentage decrease in compressive strength was found to be about 10 to $15 \%$.

2. Concrete specimens made of O.P.C content $=250 \mathrm{Kg} / \mathrm{m}^{3}$ and cured in calcium chloride solution generally resulted about $10 \%$ reduction in compressive strength meanwhile, the reduction was reduced to $5 \%$ in concrete mixes made with $\mathrm{C}=350 \mathrm{Kg} / \mathrm{m}^{3}$.

3. Using a relatively high amount of O.P.C content $(350 \mathrm{Kg} / \mathrm{m} 3)$ in concrete mixes improves both the compressive strength of concrete and its resistance against chemical attack. Increasing cement content from, 250 to $350 \mathrm{Kg} / \mathrm{m} 3$ generally increases the compressive strength by about $50 \%$.

4. The rate of decresing the compressive strengthof concrete mixes cured in the different chimical solutions is found to be highly increased with time. The percentage decrease in strength at the age of 180 days is about $20 \%$.

5. Using C-water cement in concrete mixes generally enhanced the resistance of concrete against the chemical attack when compared with identical mixes made of O.P.C.

6. A slight decrease of about $2 \%$ in density was noticed with cubes made of O.P.C. and cured in ( $5 \%$ Sodium chloride $+5 \%$ Magnesium sulfate ) solutions. This slight decrease in density may be attributed to either the effect of sulfate attack or the short period of curing them in chemical solutions.

\section{REFERENCES}

1. O. S. B. Al-Amoudi, Rasheeduzzafar, M. Maslehuddin, and S. N. Abdul-jauwad, "Influnce of chloride ions on sulphate deterioration in plain concrete and blended cements", Magazine of Concrete Research, 46 (167), 1994, pp. 113-123.

2. M. Neville and J. J. Brooks, "Concrete technology", Longman Scientific and Technical, England 1994.P. Sandberg, L. Tang, and A. Andersen, "Recurrent studies of chloride ingress in uncracked marine concrete at various exposure times and elevations", Cement and Concrete Research, 28 (10), 1998, pp. 14891503.

3. Haynes, H., O' Neil, R. and Mehta, P. K., "Concrete deterioration from physical attack by salts", Concerete International, 18 (1), 1996, pp. 63-68.

4. Mehta, P. K., "Mechanism of sulfate attack on portland cement concrete - anthor look", Cement and Concrete Research, 13 (3), 1983, 401-406.

5. Kharti, R. P., Sirivivatnanon and Yang, J. L., "Role of permeability in sulphate attack", Cement and Concrete Research, 27 (8), 1997, pp. 1179-1189.

6. Sunil Kumar, "Influence of water quilty on the strength of plain and blended cement concrete in marine environments", Cement and Concrete Research, 30, 2000, pp. 345-350.

7. K. Hong, and R. D. Hooton, "Effect of cyclic chloride exposure on penetration of concrete cover", Cement and Concerte Research, 29, 1999, pp. 1379-1386.

8. Andrew J. B. and Sidney M., "The use of tension testing to investigate the effect of w/c ratio and cement type on the resistance of concrete to sulfate attack", Cement and Concrete Research, 342004 pp. 373- 377. 
9. Al-Amoudi, O. S. B., "Attack on plain and blended cements exposed to aggressive sulphate environments, " Cement and Concrete Composite, 24, 2002, pp. 305-316.

10. Gollop, R.S. \& Taylor, H.F.W, "Microstructural and microanalytical studies of sulfate attack: 1- Ordinary portland cement paste", Cement and Concrete Research, 22(6), 1992, pp. 1027-1038.

11. J. Prasad, D.K. Jain and A.K. Ahuja, " Factors influencing the sulphate resistance of cement concrete and mortar ", Asian Journal of Civil Engineering (building and housing) Vol. 7, No. 3 (2006), pp. 259-268.

\section{تأثير نوع وكمية الأسمنت على مقاومة الخرسانة ضد الهجوم الكيميائى}

الخرسانة والمونة الأسمنتية هما من أهم المواد الإنشائية المستخدمة فى العالم بكثرة فى المنشآت

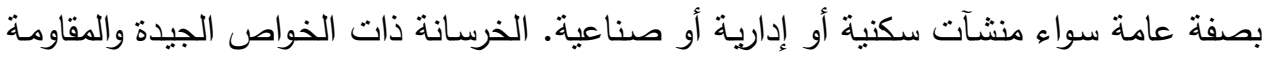
العالية هى التى تقاوم الهجوم المدمر من العمليات الفيزيائية والكيمائية التى تتتج من التفاعلات

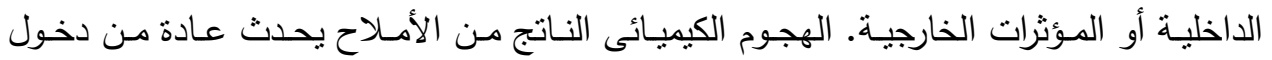

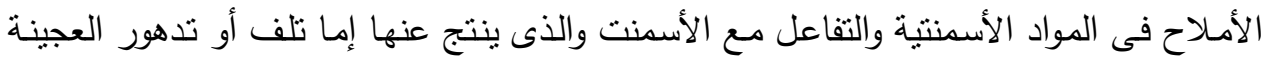

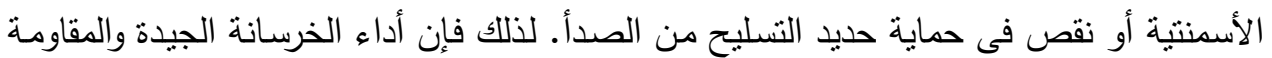

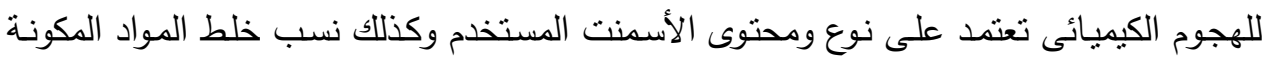
للخرسانة (أسمنت: رمل: زلط: مياه).

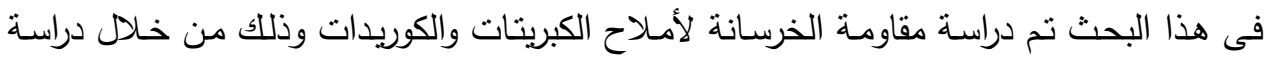
معملية عن طريق غمر مكعبات خرسانية قياسية لمدد 7 ، 28 ، 59 ، 90 ، 180 يوم فى محاليل ملحية عبارة عن :-

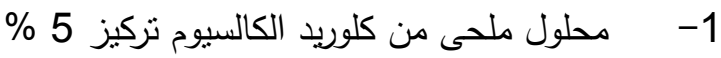

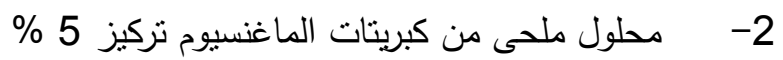
3- محلول ملحى من كلوريد الصوديوم تركيز 5 \% مختلط مع محلول مل ملحى من من كبريتات ماغنسيوم نزكيز 5 \% أيضا.

ثم تم تعيين مقاومة الضغط للخرسانة لهذه المكعبات عن طريق حساب النسبة المئوية للنقص فى لثى مقاومـة الخرسـانة المعرضـة للهجوم الكيميائى مـن المحاليل السـابقة بالمقارنـة لمقاومـة الخرسـانة

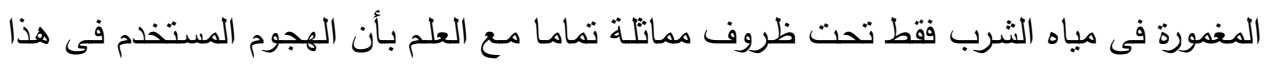
البحث هو هجوم خارجى فقط لانه الأكثر شيوعا وحدوثا للخرسانة.

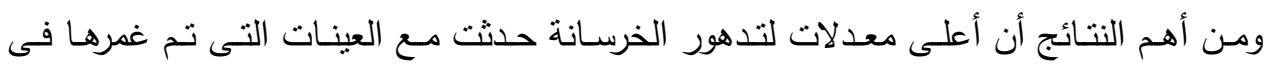
المحلول الكيميائى المكون مـن كلوريـــ الصـوديوم تركيز 5 \% مختلط مـع محلـول ملحى مـن 
كبريتات ماغنسيوم تركيز 5 \% أيضا وأن أعلى مقاومة للخرسانة حدثت مع الخرسانة الدغورة فى مياه الثرب فقط. 